\title{
Factors that Influence the Audit Report Lag Among Non-Financial Companies in Indonesia Stock Exchange
}

\author{
Vera Yusnia ${ }^{1}$, Annisa Kanti ${ }^{1 *}$ \\ ${ }^{I}$ Trisakti School of Management, Jl. Kyai Tapa No. 20. Grogol, West Jakarta, Indonesia \\ *Corresponding Author. Email : annisa@stietrisakti.ac.id
}

\begin{abstract}
Audit report lag is an indication that there is a problem in the financial statement. This study aimed to reveal some factors that can influence the audit report lag among non-financial companies listed in the Indonesia Stock Exchange (IDX). These factors include company size, company profit, solvency, public accounting firm size, independent board of commissioners, board of commissioner size, ownership concentration, independent audit committee, audit committee competency, and audit committee size. This research states that company size, company profit, solvency, board of commissioner size, ownership concentration, and audit committee size affect the audit report lag. Meanwhile, public accounting firm size, independent board of commissioners, independent audit committee, and the competence of audit committee are known to have no effect on audit report lag. In this study, solvency is known to have a positive effect on audit report lag, while company size, company profits, board of commissioner size, ownership concentration, and audit committee size negatively affect audit report lag.
\end{abstract}

Keywords: audit report lag, company size, company profit, solvency, board of commissioner size, ownership concentration

\section{INTRODUCTION}

An increase in economic growth encourages many companies to expand, as this becomes a strong reason for some of large enough companies to choose to be public companies. By becoming a public company, the company has a responsibility towards the wider community as well as the interests of stakeholders. The presentation of financial statements in accordance with the rules and standards set out in PSAK 1 will help stakeholders clearly understand the financial information regarding the company. However, in practice, many companies do not follow the stipulated conditions. This causes the level of public trust to decline. So, to restore this trust, public companies are required to submit the audited financial reports.

Audit report lag not only gives a negative reaction to investors, but will also harm the company's concerns. In addition, the delay in financial reports for more than 4 months will be subject to fines and administrative sanctions. The factors that cause the audit report lag do not only come from internal factors, but also from external factors. The company's internal factors are determined by company size, operating profit, solvency, ownership concentration, and other matters which include the board of commissioners and the audit committee. Meanwhile, the company's external factors are determined by the size of public accounting firm. Company size can influence the audit report lag, because the bigger the company is, the tendency to have good internal control can lower the possibility of audit report lag. In another case, a larger company is possible to experience the audit report lag, because it often has the total value of major assets that are more complex with intense operational activities. Profitability is known as good news for the stakeholders, so the company tend to spread it as soon as possible, therefore, it reduces the audit repot lag. Solvency can affect the audit report lag, because high solvency implies the level of risk in the company's finance. Public Accounting Firm size affects audit report lag, because high quality auditors have a greater opportunity to use significant resources to conduct the audit process. Independent Board of Commissioners $(\mathrm{BoC})$ reflects the number of $\mathrm{BoC}$ that acts independently, so it helps company to conduct the practice of good corporate governance, hence this relationship also supports the agency theory. BoC size can influence the audit report lag, because the bigger the $\mathrm{BoC}$ will encourage the members who focus on each department in order to do the monitoring and coordinating activities. Ownership Concentration can affect the audit report lag, because a company with concentrated ownership is expected to provide information quickly with a concentrated command. Independent Audit Committee affects the audit report lag by providing an effective oversight and independence. Audit Committee Competence can influence the audit report lag, because the audit committee with a background in financial education tends to understand the company's financial statements conditions. Audit Committee Size can influence the audit report lag, because many audit committees will provide more adequate and detailed supervision.

The phenomenon of the audit report lag case can be recognized through the case of Mutiara Bank or better known as Century Bank. Century Bank is known to have been late in submitting its financial reports for the year 2011 . 
On May $9^{\text {th }}, 2012$, the stock exchange gave a written warning to Mutiara Bank due to the delay, but until the due date, Mutiara Bank had not yet submitted its financial reports. This delay caused major problems for Mutiara Bank and had an impact on the value of Mutiara Bank shares.

This research is a development from previous research, namely The Influence of Company Size, Company Profit, Solvency, and CPA Firm Size on Audit Report Lag by [24]. The difference between this research and the previous research is that previous research was conducted during 2013-2015, while this research was conducted during 20162018. The number of variables in the previous research were 4 independent variables consisting of company size, company profit, solvency, and size of Public Accounting Firm, as well as 1 dependent variable on audit report lag. Meanwhile, in this research, 6 independent variables were added, namely the independent $\mathrm{BoC}$, size of $\mathrm{BoC}$, ownership concentration, independent audit committee, competence of audit committee, and size of audit committee. These variables were obtained from the journal entitled 'The effect of board of commissioners, audit committee, and stock ownership concentration on audit report lag of banking companies in Indonesia Stock Exchange' by [30].

Based on the background of the problems stated above, the main issue to be raised in this study is whether company size, company profit, solvency, public accounting firm size, independent $\mathrm{BoC}$, size of $\mathrm{BoC}$, ownership concentration, independent audit committee, competence of the audit committee, and size of the audit committee have an influence on the audit report lag. The objective that the researchers want to achieve is to obtain an empirical evidence regarding the effect of company size, company profit, solvency, public accounting firm size, independent board of commissioners, size of the board commissioners, ownership concentration, independent audit committee, competence of the audit committee and size of the audit committee on audit report lag. Through this research, it is hoped that it can be useful for investors, companies, and further research in order to provide a full information about the assessment given to company performance to be carried out appropriately by considering the factors that can cause a company to experience an audit report lag.

\section{LITERATURE REVIEW}

\subsection{Agency Theory}

Agency theory explains the relationship between the owner (agent) who has the authority in decision making and the shareholders (principal), namely the management who manages the company's assets and compiles the company's financial statements [17]. The tendency of shareholders to get high returns often cannot occur due to management's focus on short-term performance, which creates the agency problems.

To mediate the interest in managing the company's financial statements, the role of an auditor is required. The company's financial statements will be audited later by auditors which will be used for principal decision making.

\subsection{Company Size and Audit Report Lag}

Research by [21] [22] [3] stated that company size has a positive influence on audit report lag, because company size, which has a large total main asset value, becomes more complex which tend to spend more time in conducting the audit examinations. [24] [5] provide a different view that company size has a negative influence on the audit report lag. Meanwhile, according to [14], company size has no effect on audit report lag.

$\mathrm{H}_{1}$ : Company size affects the audit report lag.

\subsection{Profitability and Audit Report Lag}

[24] and [4] found that company profits have a negative effect on audit report lag. The company's profit is considered as good news so that the management of reports that have experienced profits will be more quickly delivered by management. Meanwhile, through the research of [9], it was found that company profits had no influence on audit report lag.

$\mathrm{H}_{2}$ : Profitability affects the audit report lag.

\subsection{Solvency and Audit Report Lag}

Research by [5] and [29] show that solvency positively affects the audit report lag. High solvency reflects the level of risk in the company's finances, and public realizes that financial problems in the company are bad news. However, research by [24] and [18] stated that solvency has no influence on the audit report lag.

$\mathrm{H}_{3}$ : Solvency affects the audit report lag.

\subsection{Public Accounting Firm Size and Audit Report Lag}

[11] revealed that the size of public accounting firm has a positive effect on audit report lag. On the other hand, the research by [27] and [13] stated that the size of public accounting firm negatively affects the audit report lag. A public accounting firm with a large size can complete an audit report in shorter time than does an ordinary public accounting firm. However, through the research by [24] and [6], it was found that the size of public accounting firm has no effect on audit report lag.

$\mathrm{H}_{4}$ : Public accounting firm size affects the audit report lag.

\subsection{Independent BoC and Audit Report Lag}

[10] and [12] revealed that the independent BoC significantly affects the audit report lag. The research finding is in line with the agency theory, in which the result of the relationship between corporate governance mechanisms and the audit report lag is generally significant. Meanwhile, [26] stated that the independent BoC negatively affects the audit report lag. The study by [15] and [30] stated that the independent board of commissioners has no influence on audit report lag. 
$\mathrm{H}_{5}$ : Independent BoC affects the audit report lag.

\subsection{BoC Size and Audit Report Lag}

Research by [30] and [32] stated that the size of board of commissioners has a significant effect on audit report lag. The number of BoC owned in a company can influence the length of the audit report lag. However, the research by [12] and [16] stated that it negatively affects the audit report lag. Meanwhile, through the research by [19], it was found that the size of BoC does not affect the audit report lag.

$\mathrm{H}_{6}$ : BoC size affects the audit report lag.

\subsection{Ownership Concentration and Audit Report Lag}

Based on the research conducted by [7], ownership concentration positively affects the audit report lag. Share ownership in companies that tend to be concentrated, will make them faster to publish their financial reports in time. Meanwhile, [8] argued that ownership concentration negatively affects the audit report lag. According to [30], ownership concentration does not influence the audit report lag.

$\mathrm{H}_{7}$ : Ownership concentration affects the audit report lag.

\subsection{Independent Audit Committee and Audit Report Lag}

Research conducted by [32] revealed that the independent audit committee negatively affects the audit report lag. The more independent parties are in the supervision, it is expected that the more effective the supervision will be. However, the research conducted by [30] and [19] revealed that the independent audit committees does not significantly affect the audit report lag.

$\mathrm{H}_{8}$ : Independent Audit Committee affects the audit report lag.

\subsection{Audit Committee Competence and Audit Report Lag}

According to [32], the competence of audit committee positively affects the audit report lag. Audit members who have a background in accounting competence, are considered to be more able to control the company's operational and financial conditions. Meanwhile, the research by [28] is in line with [30] mentioning that the competency variable has no effect on audit report lag. $\mathrm{H}_{9}$ : Audit committee competence affects the audit report lag.

\subsection{Audit Committee Size and Audit Report Lag}

[23] revealed that the size of audit committee positively affects the audit report lag. However, the research conducted by [1] revealed that the size of audit committee negatively affects the audit report lag, which means that the implementation of good corporate governance is proven to reduce the delays in audit reports. Meanwhile, according to the research by [30] and [1], the size of audit committee has no effect on audit report lag.

$\mathrm{H}_{10}$ : Audit committee size affects the audit report lag.

The following figure is an illustration of the research model in this study.

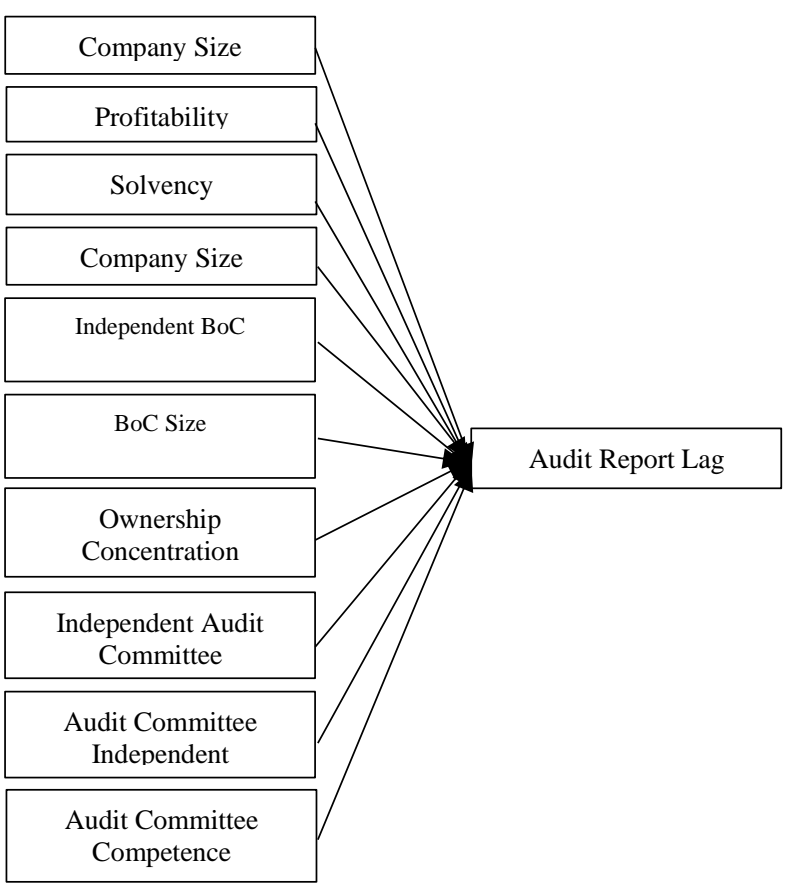

Figure 1 Research Model

\section{RESEARCH METHODS}

Researchers used the method with a causality design. This study used data panel, which is a combination of cross sectional and time-series data. This study used a purposive sampling method in which the determination of special characteristics is in accordance with the research objectives so that the research problems can be resolved [31]. There are several criteria used for sample selection, among others are: (1) Non-financial companies that are consistently listed in the IDX during the period of 2016 - 2018, (2) Nonfinancial companies whose financial statements ended in December $31^{\text {st }}$ for the period of 2016 - 2018, (3) Nonfinancial companies that use the IDR currency in their financial statements for the period of 2016 - 2018, (4) Nonfinancial companies that have an audit committee composition from the year 2016 to 2018 .

The objects to be examined in this study are non-financial companies listed in the IDX with an observation period of 2016-2018.

Audit report lag is symbolized by ARL. According to [24], the measurement is as follow:

Audit Report Lag $=$ The time length between the date of financial statements and the date of audit opinion. 
Company size is symbolized by FSIZE. The measurement used by [24] is as follow:

FSIZE $=$ Log $($ Total Assets $)$

Company profit is symbolized by PROFT. The measurement of this variable according to [22] is to use one of the profitability ratios, namely return on assets (ROA):

Return on Asset $=($ Net Profit $) /($ Total Asset $)$

Solvency is symbolized by SOLV as the measurement used by [24] using a debt to assets (DAR) ratio, whereas the formula is as follow:

$$
\text { Debt Ratio }=(\text { Total Debt }) /(\text { Total Asset })
$$

Public accounting firm size is symbolized by CPASIZE with the measurement used by [24] using a dummy variable (1) for companies whose financial statements use audit services by the BIG Four Public Accounting Firm and (0) for those using non-BIG Four Public Accounting Firm's auditing services.

The independent board of commissioners is symbolized by IBOC with the measurements used by [30] as follow:

$$
I B O C=\frac{\sum \text { Independent Board of Commissioners }}{\sum \text { Board of Commissioners }}
$$

The size of BoC is symbolized by BCSIZE. Research by [30] measured the size of BoC as follow:

Board of Commissioners Size $=$ Number of Commissioners

Ownership concentration is symbolized by OWNCON. In the research by [30], the measurement was carried out as follow:

OwnershipConcentration

SOutstandingSharesOwnedbyTheFiveLargestShareholders $\sum$ TotalValueof SharesOutstanding

The independent audit committee is symbolized by ACIN. The measurement of audit committee size variable in [30] is as follow:

Independence of Committee Audit $=\frac{\sum \text { Independent Parties }}{\sum \text { Audit Committee }}$

Competence of the audit committee is symbolized by ACCO. In the study by [30], this variable is measured with the following formula:

The size of the audit committee is symbolized by ACSIZE.

AuditCommitteCompetence
$\sum$ AuditCommitteeMemberswithAccounting\&FinancialBackgr
$\sum$ AuditCommittee

The measurement of the audit committee size variable in [30] is based on the number of members of audit committee.

Audit Committee Size $=$ Number of Audit Committee Members

The data processing method that was carried out in this study is using the secondary data. The data was collected from the IDX website with the url address: www.idx.co.id. The company, whose data was taken, was a company that met the criteria set during the period of 2016-2018 and had a book-closing date on December $31^{\text {st }}$.

Analysis on this data was carried out using descriptive statistical methods. A data description is seen through the mean which shows the average value of the sample, the range shows the difference between the maximum and the minimum values, skewness functions to adjust the slope of data distribution, and kurtosis functions to measure the peak of data distribution.

We also used the data quality test which included the normality test (using one sample Kolmogorov-Smirnov test), outlier test (for data with extreme values), classicalassumption test (autocorrelation test using BreuschGodfrey test), multicollinearity test, heteroscedasticity test), hypothesis test using multiple regression analysis, correlation coefficient analysis (R), analysis of the coefficient of determination (Adj. R-Square), F-Test (ANOVA) and t-statistical Test.

The regression model equation in this research could be developed as follow:

$\mathrm{ARL}=\beta_{0}+\beta_{1}$ CSIZE $+\beta_{2}$ PROFT $+\beta_{3}$ SOLV $+\beta_{4}$ CPASZE $+\beta_{5}$ IBOC $+\beta_{6}$ BCSIZE $+\beta_{7}$ OWNCON $+\beta_{8}$ $\mathrm{ACIN}+\beta_{9} \mathrm{ACCO}+\beta_{10} \mathrm{ACSIZE}+\varepsilon$

\section{RESEARCH RESULTS}

\begin{tabular}{|c|c|c|c|}
\hline No & Criteria Description & $\begin{array}{l}\text { Number of } \\
\text { Companies }\end{array}$ & $\begin{array}{l}\text { Total } \\
\text { Data }\end{array}$ \\
\hline 1 & $\begin{array}{l}\text { Non-financial companies that are } \\
\text { consistently listed in the IDX } \\
\text { during the period of } 2016-2018\end{array}$ & 434 & 1,302 \\
\hline 2 & $\begin{array}{l}\text { Non-financial companies whose } \\
\text { financial statements do not end at } \\
31 \text { December during the period } \\
2016 \text { to } 2018\end{array}$ & (18) & $(54)$ \\
\hline 3 & $\begin{array}{l}\text { Non-financial companies whose } \\
\text { financial statements do not use the } \\
\text { Indonesian Rupiah during the } \\
\text { period } 2016-2018\end{array}$ & (83) & $(249)$ \\
\hline 4 & $\begin{array}{l}\text { Non-financial companies that have } \\
\text { no audit committee composition } \\
\text { from } 2016 \text { to } 2018\end{array}$ & (1) & (3) \\
\hline & The total data used as a sample is & 332 & 996 \\
\hline
\end{tabular}

Table 1 Research Sample Selection Procedure 
There are 434 companies in the non-financial sector listed in the IDX during the period of 2016 - 2018. Through predetermined criteria, it was found that only 332 companies met the authors' criteria. No data was discarded in this study due to the outlier-test, because the data under study still showed that the result was not normally distributed.

\section{The Result of Data-Quality Test (Normality Test)}

The result of normality test on research data using one sample Kolmogorov-Smirnov test shows that the Asymp value. Sig (2-tailed) in the normality test is 0.000 , which is less than alpha (0.05). So, it can be concluded that the residual data of the variables that have been tested is not normally distributed, so it is necessary to carry-out an outlier test. After conducting the Outlier-Test, the result of normality test shows the Asymp number. Sig (2-tailed) of 0.000 , whereas the value is less than alpha (0.05), which means that the data is not normally distributed again. Based on these results, the next test would use the data before the outlier-test was carried out, namely with 993 research data. This is due to the data that remains not normally distributed after conducting the outlier-test.

\section{Classical-Assumption Tests}

\section{Auto-Correlation Test}

As the result of auto-correlation test, the Sig. res_2 is 0.027, which is smaller than alpha (0.05). So, it can be concluded that, in this regression model, there is a positive autocorrelation which indicates an error followed with the same sign. Testing with auto-correlation result often occurs in time-series data because of the influence of previous period data on the current data.

Thus, it is necessary to re-test to ensure whether or not there is an auto-correlation problem that occurs. Therefore, the researchers conducted a run-test to solve the autocorrelation problem. The result of run-test is obtained through the Asymp. value. Sig. (2-tailed). If the value is greater than 0.05 , then the autocorrelation does not occur. Based on the result of run-test, the value obtained is 0.727 , which is higher than alpha (0.05). Hence, the tested data is considered free from the auto-correlation problem.

\section{Table 2 Multicollinearity Test Result}

\begin{tabular}{llll}
\hline Variable & Tolerance & VIF & Conclusion \\
\hline CSIZE & 0.587 & 1.705 & Multicollinearity does not occur \\
PROFT & 0.727 & 1.375 & Multicollinearity does not occur \\
SOLV & 0.750 & 1.333 & Multicollinearity does not occur \\
CPASIZE & 0.753 & 1.328 & Multicollinearity does not occur \\
IBOC & 0.971 & 1.030 & Multicollinearity does not occur \\
BCSIZE & 0.683 & 1.464 & Multicollinearity does not occur \\
OWNCON & 0.935 & 1.069 & Multicollinearity does not occur \\
ACIN & 0.931 & 1.074 & Multicollinearity does not occur \\
ACCO & 0.955 & 1.047 & Multicollinearity does not occur \\
ACSIZE & 0.870 & 1.149 & Multicollinearity does not occur \\
\hline
\end{tabular}

Source: The result of data processing using SPSS v.25
The multicollinearity test result on the research data showed that multicollinearity did not occur among the independent variables tested.

Table 3 Heteroscedasticity Test

\begin{tabular}{lll}
\hline Variable & Sig. & \multicolumn{1}{c}{ Conclusion } \\
\hline CSIZE & 0.414 & Heteroscedasticity does not occur \\
PROFT & 0.003 & Heteroscedasticity occurs \\
SOLV & 0.582 & Heteroscedasticity does not occur \\
CPASIZE & 0.830 & Heteroscedasticity does not occur \\
IBOC & 0.247 & Heteroscedasticity does not occur \\
BCSIZE & 0.046 & Heteroscedasticity occurs \\
OWNCON & 0.016 & Heteroscedasticity occurs \\
ACIN & 0.373 & Heteroscedasticity does not occur \\
ACCO & 0.068 & Heteroscedasticity does not occur \\
ACSIZE & 0.232 & Heteroscedasticity does not occur \\
\hline Source: The result of data processing using SPSS v.25
\end{tabular}

Based on the test result, it was found that in the independent variable of company size, solvency, public accounting firm size, independent board of commissioners, independent audit committee, audit committee competence, and audit committee size, heteroscedasticity does not occur, because the significance value of each variable is above 0.05 . Thus, it is good to use it in this research. However, there are also 3 independent variables in this test that contain heteroscedasticity, namely the variable of company profit, the size of BoC, and the ownership concentration, which have significance values below 0.05 . Therefore, this results in the data not being used in this research.

\section{Hypothesis Test}

\section{Correlation-Coefficient Analysis (R)}

The result of $\mathrm{R}$ value of 0.402 means that the relationship between the independent variables and the audit report lag is moderate.

\section{Analysis of the Coefficient of Determination (Adj. R - Square)}

In this study, the value of Adjusted- $\mathrm{R}^{2}$ is $15.3 \%$, which means that the variation in the audit report lag as the dependent variable can be explained by the variation in the independent variables only as much as $15.3 \%$. Meanwhile, the remaining $84.7 \%$ of variation in the audit report lag is determined by other variables not included in this regression model.

\section{F-Test (ANOVA)}

The F-test obtained a significance value of 0.000 , in which the value is smaller than alpha (0.05). Thus, it can be concluded that the regression model in this study is fit for use. 
Table 4 The Results of t-Statistical Tests

\begin{tabular}{lccl}
\hline & $\begin{array}{c}\text { B (Unstandardized } \\
\text { Coefficients) }\end{array}$ & Sig. & Decision \\
\hline (constant) & 174.002 & 0.000 & \\
CSIZE & -4.669 & 0.000 & $\mathrm{H}_{1}$ accepted \\
PROFT & -17.878 & 0.000 & $\mathrm{H}_{2}$ accepted \\
SOLV & 2.355 & 0.000 & $\mathrm{H}_{3}$ accepted \\
CPASIZE & 2.226 & 0.217 & $\mathrm{H}_{4}$ not accepted \\
IBOC & 9.060 & 0.181 & $\mathrm{H}_{5}$ not accepted \\
BCSIZE & -1.849 & 0.000 & $\mathrm{H}_{6}$ accepted \\
OWNCON & -15.772 & 0.000 & $\mathrm{H}_{7}$ accepted \\
ACIN & -7.800 & 0.411 & $\mathrm{H}_{8}$ not accepted \\
ACCO & -4.242 & 0.169 & $\mathrm{H}_{9}$ not accepted \\
ACSIZE & -3.823 & 0.048 & $\mathrm{H}_{10}$ accepted \\
Source: The result of data processing SPSS using v.25
\end{tabular}

The regression equation in the study is as follow:

$\mathrm{ARL}=174.002-4.669 \mathrm{CSIZE}-17.878 \mathrm{PROFT}+2.355$

SOLV + 2.226 CPASIZE + 9.060 IBOC -1.849

BCSIZE - 15.772 OWNCON - 7.800 ACIN - 4.242

$\mathrm{ACCO}-3.823$ ACSIZE $+\varepsilon$

From the results of the t-statistical tests in Table 5, it can be concluded that:

The company size variable (CSIZE) has a beta coefficient of -4.669 and a significance value of 0.000 , which is smaller than alpha (0.05). So, $\mathrm{H}_{1}$ was accepted. This means that company size has a negative effect on the audit report lag. Companies with large amounts of assets will tend to report their financial statements punctually, because this is due to the responsibilities of parties who have an interest in the financial statements.

The company profit variable (PROFT) has a beta coefficient of -17.878 and a significance value of 0.000 . So, $\mathrm{H}_{2}$ was accepted. This means that company profit has a negative effect on the audit report lag. Profits are good news for the company so that the news will make the company submit the report to public as quickly as possible, in contrast to losses.

Solvency variable (SOLV) has a beta coefficient of 2.355 and a significance value of 0.000 . So, $\mathrm{H}_{3}$ was accepted. This means that solvency positively affects the audit report lag. High solvency can reflect the level of risk in a company's finances. The public realizes financial problems in a company as bad news, and this can cause the management decide to postpone its financial reports.

The variable of Public Accounting Firm size (CPASIZE) has a beta coefficient of 2.226 and a significance value of 0.217. So, $\mathrm{H}_{4}$ was not accepted. This means that the size of Public Accounting Firm has no effect on the audit report lag. This is because the difference in audit efficiency is not determined by size, but by the effectiveness of the audit methodology and its commitment to meeting the expectations of the company as a client.

The Independent Board of Commissioners (IBOC) variable has a beta coefficient of 9.060 and a significance value of
0.181. So, $\mathrm{H}_{5}$ was not accepted. This means that the percentage of independent commissioners in a company has no effect on the occurrence of audit report lag. The number of independent commissioners in the company will only help the company act in accordance with its objectives properly without any interference from stakeholders and will not affect the delay in financial statements.

The variable size of the Board of Commissioners (BCSIZE) has a beta coefficient of -1.849 and a significance value of 0.000 . Thus, $\mathrm{H}_{6}$ was accepted. This means that the size of BoC negatively affects the audit report lag. The more the number of BoC is, the more focused a company is on each department so that the implementation of management tasks can be coordinated more effectively.

Ownership Concentration (OWNCON) variable has a beta coefficient of -15.772 and a significance value of 0.000 . Thus, $\mathrm{H}_{7}$ was accepted. This means that ownership concentration negatively affects the audit report lag. Ownership concentration can help reduce the agency problems that occur between shareholders and management, because the largest shareholder has the power to carry out the monitoring and control functions of the management [8].

The Independent Audit Committee (ACIN) variable has a beta coefficient of -7.800 and a significance value of 0.411 . Thus, $\mathrm{H}_{8}$ was not accepted. This means that the independent audit committee does not significantly influence the audit report lag. The performance of an independent audit committee within a company is one of the steps to fulfil the requirements made by the Financial Services Authority (FSA) so that this does not affect the occurrence of delays in submitting financial reports.

The variable of competency of the Audit Committee (ACCO) has a beta coefficient of -4.242 and a significance value of 0.169 . Thus, $\mathrm{H}_{9}$ was not accepted. This means that the competence of audit committee does not affect the audit report lag. People who have background in certain fields, may not have sufficient competence or expertise required.

The Audit Committee Size variable (ACSIZE) has a beta coefficient of -3.823 and a significance value of 0.048 . Thus, $\mathrm{H}_{10}$ was accepted. This means that the size of audit committee negatively affects the audit report lag. The implementation of good corporate governance in the company, which implies the need for an audit committee, is proven to reduce delays in audit reports.

\section{CONCLUSIONS, LIMITATIONS, AND SUGGESTIONS}

This research was conducted using the IBM SPSS ver.25 program with the results of the research stating that there are several alternative hypotheses that could not be accepted. The results of testing on 332 sample company data can be concluded as follows: 
1. Company size negatively affects the audit report lag. The result of this study is in line with [24], which becomes the main source of this research. In contrast, the result of this study is inconsistent with [21] and [3]. Meanwhile, it was found that there is no influence of company size on audit report lag in the research by [14].

2. Company earnings has a negative effect on audit report lag. The result of this study is consistent with [24] and [4]. However, the result of this study is different from the research conducted by [9], which stated that company profit has no effect on audit report lag.

3. Solvency has a positive effect on the audit report lag. This result is inconsistent with the research conducted by [24]. However, this study is similar with [5] [21] [29], which stated that solvency has a positive effect on audit report lag.

4. Public accounting firm size does not significantly affect the audit report lag. This result is in line with [24] and [6]. Meanwhile, according to the research conducted by [11], the size of public accounting firm has a positive effect on audit report lag. According to [27] and [13], Public Accounting Firm size has a negative effect on audit report lag.

5. The Independent Board of Commissioners has no influence on audit report lag. The result of this study is inconsistent with the research by [26], which stated that this variable negatively affects the audit report lag. Meanwhile, according to [10], the independent board of commissioners significantly affects the audit report lag. However, the result of this study is consistent with [30] and [15].

6. The size of board of commissioners has a negative effect on audit report lag. This result is similar with [30]. The result of this study is different from [32], which stated that the size of $\mathrm{BoC}$ has a positive influence on audit report lag.

7. Ownership Concentration has a negative effect on audit report lag. This finding is inconsistent with [30]. However, this study is consistent with [8]. In contrast to those two studies, [7] stated that there is a positive influence of ownership concentration on the audit report lag.

8. The Independent Audit Committee does not significantly affect the audit report lag. This finding is similar with [30] and [19]. However, this finding is different from [32], which stated that the independent audit committee negatively affects the audit report lag.

9. The competence of Audit Committee has no effect on the audit report lag. This is consistent with [30] and [28]. However, this result is not consistent with [32], which stated that the competence of Audit Committee has a positive effect on the audit report lag.

10. The size of Audit Committee negatively affects the audit report lag. According to [2] [30] and [25], the size of audit committee does not significantly affect the audit report lag. Meanwhile, the research conducted by [23] showed that the size of audit committee positively affects the audit report lag. However, this study is in line with [1].
The results of this research show that solvency positively affects the occurrence of audit report lag. Company size, profitability, BoC size, ownership concentration, and audit committee size have a negative effect on audit report lag. Meanwhile, the size of public accounting firm, the independent $\mathrm{BoC}$, the independence of audit committee, and the competence of audit committee have no effect on the occurrence of audit report lag. During this compilation process, there are several limitations that the authors can conclude, among others are:

1. The period in this research is relatively short, namely for three years of observation starting from the year 2016 to 2018.

2. This study uses 10 independent variables, namely company size, profitability, solvency, public accounting firm size, independent board of commissioners, board of commissioner size, ownership concentration, independent audit committee, audit committee competence, and audit committee size, which can only explain the effect as much as $15.3 \%$ toward the dependent variable. This effect is relatively small and it is suspected that there are other variables outside this study that can explain the effect more relevant.

3. The research data was not normally distributed even though the outlier testing and elimination of outlier data had been carried-out against the tested data.

4. There are 3 variables that have the effect of heteroscedasticity, which are company profit, board of commissioner size, and ownership concentration.

Based on these limitations, the authors describe several suggestions that can be used by further researchers, among others are:

1. The research period can use a relatively longer time, such as the observation for 5 years or more.

2. The use of other independent variables can explain the relevant effects on the audit report lag such as liquidity, financial distress, audit tenure, and so on.

3. Future researchers can overcome the data problem that is not normally distributed by checking the data again and adding or avoiding the data that is too extreme in the research.

4. Future researchers can conduct several tests that can overcome the heteroscedasticity effect such as using the generalized least squares (GLS) method or performing data transformation.

\section{REFERENCES}

[1] Abdillah, Selvy Yulita, R. Anastasia Endang Susilawati dan Nanang Purwanto. 2016. Pengaruh Good Corporate Governance pada Manajemen Laba (Studi Empiris pada Perusahaan Manufaktur yang Terdaftar di Bursa Efek Indonesia Tahun 2013-2014). Jurnal Riset Mahasiswa Akuntansi, 4(1). 
[2] Ahmed, Mohammed Ishaq dan Ayoib Che-Ahmad. 2016. Effects of Corporate Governance Characteristics on Audit Report Lags. International Journal of Economics and Financial Issues, 6(S7), 159-164.

[3] Arifuddin, Kartini Hanafi dan Asri Usman. 2017. Company Size, Profitability, and Auditor Opinion Influence to Audit Report Lag on Registered Manufacturing Company in Indonesia Stock Exchange. International Journal of Applied Business and Economic Research, 15(19), 353-367.

[4] Aristika, Manda Novy, Rina Trisnawati dan Cahyaning Dewi Handayani. 2016. Pengaruh Opini Audit, Ukuran Perusahaan, Umur Perusahaan dan Laba Rugi Terhadap Audit Report Lag. Syariah Paper Accounting FEB UMS.

[5] Artaningrum, Rai Gina. 2018. Pengaruh Profitabilitas, Solvabilitas, Likuiditas, Ukuran Perusahaan, Pergantian Manajemen dan Reputasi KAP pada Audit Report Lag Perusahaan Perbankan. LP2M Undhira Bali.

[6] Baldacchino, Peter J., Loraine Grech, Konrad Farrugia dan Norbert Tabone. 2017. An analysis of audit report lags in maltese companies. Studies in Economic and Financial Analysis, 98, 161-182.

[7] Basuony, Mohamed A.K., Ehab K.A. Mohamed, Mostaq M. Hussain, dan Omar K. Marie. 2016. Board characteristics, ownership structure and audit report lag in the Middle East, 7(2), 181-205.

[8] Butarbutar, Rizki Sakti Kornelius dan P. Basuki Hadiprajitno. 2017. Analisis Faktor-Faktor yang Berpengaruh terhadap Audit Report Lag. Diponegoro Journal of Accounting, 6(3), 1-12.

[9] Charviena dan Elisa Tjhoa. 2016. Pengaruh Ukuran Perusahaan, Laba Rugi Operasi, Solvabilitas, Umur Perusahaan, Klasifikasi Industri, dan Ukuran KAP terhadap Audit Delay. Ultima Accounting, 8(2), 66-88.

[10] Daoud, Khaldoon Ahmad Al, Ku Nor Izah Ku Ismail dan Nor Asma Lode. 2015. The Impact of Internal Corporate Governance on the Timeliness of Financial Reports of Jordanian Firms: Evidence using Audit and Management Report Lags. Mediterranean Journal of Social Sciences, 6(1), 430-442.
[11] Evans, Rusmin Rusmin John. 2017. Audit quality and audit report lag: Case of Indonesian listed companies. Asian Review of Accounting, 25(2), 1-30.

[12] Faishal, Muhammad dan P.Basuki Hadiprajitno. 2015. Pengaruh mekanisme good corporate governance terhadap audit report lag. Diponegoro journal of accounting, 4(4), 1-11.

[13] Farag, Magdy. 2017. The impact of accelerated filing requirements on meeting audit report deadlines. Accounting Research Journal, 30(1), 1-26.

[14] Halim, Yansen Cristian. 2018. Faktor-Faktor yang Mempengaruhi Audit Report Lag Periode 2013-2016 di Bursa Efek Indonesia. Jurnal Muara Ilmu Ekonomi dan Bisnis, 2(1), 54-63.

[15] Isnania, Siti Akhrani, Edi Sukarmanto dan Mey Maemunah. 2017. Pengaruh Komite Audit, Dewan Komisaris Independen dan Reputasi KAP terhadap Audit Report Lag. Prosiding Akuntansi, 4(1), 40-45.

[16] Jao, Robert dan Feby Pebriyanti Crismayani. 2018. Pengaruh Mekanisme Corporate Governance Terhadap Audit Delay. Prosiding Seminar Hasil Penelitian (SNP2M), 87-92.

[17] Jensen, M.C. dan W.H. Meckling. 1976. Theory of the firm: Managerial Behavior, Agency Costs and Ownership structure. Journal of Financial Economics 3, 305-360.

[18] Juanita, Greta dan Rutji Satwiko. 2012. Pengaruh Ukuran Kantor Akuntan Publik, Kepemilikan, Laba Rugi, Profitabilitas dan Solvabilitas Terhadap Audit Report Lag. Jurnal Bisnis dan Akuntansi, 14(1).

[19] Kusumah, R.Wedi Rusmawan dan Daniel T.H. Manurung. 2017. Pentingkah Good Corporate Governance bagi Audit Report Lag? Jurnal Akuntansi Multiparadigma, 8(1), 137-148.

[20] Latif, Syahid. 28 November 2013. Bank Mutiara 3 Kali Telat Serahkan Laporan Keuangan. Liputan6.com, (https://www.liputan6.com/bisnis/ read/758953/bankmutiara-3-kali-telat-serahkan-laporan-keuangan, 10 September 2019)

[21] Lianto, Novice dan Budi Hartono Kusuma. 2010. Faktor-Faktor yang Berpengaruh terhadap Audit Report Lag. Jurnal Bisnis dan Akuntansi, 12(2), 98-107. 
[22] Lisdara, Nada, Roni Budianto dan Roza Mulyadi. 2019. Pengaruh Ukuran Perusahaan, Laba Perusahaan, Solvabilitas, dan Ukuran Kantor Akuntan Publik terhadap Audit Report Lag. Jurnal Riset Akuntansi Terpadu, 12(2), 167-179.

[23] Mahendra, A.A Ngurah Putu dan Ni Luh Sari Widhiyani. 2017. Pengaruh GCG, Opini Auditor, dan Internal Auditor terhadap Audit Delay pada Perusahaan Telekomunikasi di BEI. E-Jurnal Akuntansi Universitas Udayana, 21, 1601-1629.

[24] Mutiara, Yosia Taruli, Adam Zakaria dan Ratna Anggraini. 2018. The Influence of Company Size, Company Profit, Solvency and CPA Firm Size on Audit Report Lag. Journal of Economics, Finance and Accounting, 5(1), 1-10.

[25] Noeryanto, Handy. 2015. Faktor-Faktor yang Berpengaruh Terhadap Audit Report Lag pada Perusahaan Non Keuangan. Jurnal Bisnis dan Akuntansi Vol.17 No.1a.

[26] Ovami, Debbi Chyntia dan Reza Hanafi Lubis. 2018. Pengaruh Corporate Governance dan Profitabilitas terhadap Audit Report Lag pada Perusahaan Real Estate dan Property. Kitabah Vol.2 No.1.

[27] Pramaharjan, Brian dan Nur Cahyonowati. 2015. Faktor faktor yang berpengaruh terhadap Audit Report Lag pada perusahaan manufaktur. Diponegoro journal of accounting, 4(4), 1-8.

[28] Salleh, Zalailah, Saeed Rabea Baatwah dan Norsiah Ahmad. 2017. Audit Committee Financial Expertise and Audit Report Lag: Malaysia Further Insight. Asian Journal of Accounting and Governance 8, 137-150.

[29] Sastrawan, I Putu dan Made Yenni Latrini. 2016. Pengaruh Profitabilitas, Solvabilitas, dan Ukuran Perusahaan terhadap Audit Report Lag pada Perusahaan Manufaktur. E-Jurnal Akuntansi Universitas Udayana, 17(1), 311-337.

[30] Setiawan, Ganang dan Nahumury. 2014. The effect of board of commissioners, audit committee, and stock ownership concentration on audit report lag of banking companies in Indonesia Stock Exchange. The Indonesian Accounting Review, 4(1), 15-28.
[31] Sugiyono. 2016. Metode Penelitian Kuantitatif, Kualitatif, dan R\&D. Bandung: Alfabeta.

[32] Wardhani, Armania Putri dan Surya Rahardja. 2013. Analisis Pengaruh Corporate Governance Terhadap Audit Report Lag. Diponegoro Journal of Accounting, 2(3), 1-11. 